\section{POST OCCUPANCY EVALUATION IN THE PRACTICE OF ARCHITECTURE: A CASE STUDY OF LÜTFI KIRDAR CONVENTION AND EXHIBITION CENTRE}

\author{
Ali Murat TANYER and Tuğba PEMBEGÜL
}

Received: 25.08.2009; Final Text: 24.03.2010

Keywords: convention centre; Post Occupancy Evaluation (POE); Importance - Performance Analysis (IPA).

1. This paper is based on Pembegül (2009).

\section{INTRODUCTION}

In recent years, changing market conditions and limitations on resources have put enormous stress on the construction industry (1). Projects' scope gets complex and clients / owners are now asking construction professionals to deliver more qualified products for less budget. In order to achieve a more effective project delivery mechanism, getting constructive feedback from previously implemented projects is getting more and more important.

Evaluating the performance of buildings after they have been occupied is an important step of project life cycle that provides feedback to the professionals related to the building. This systematic and detailed inspection, carried out with the users of the building, is called Post Occupancy Evaluation (POE). POE provides credible evidence about the positive and negative aspects of the buildings from the users' point of view. As a result of ensuring that feedback is applied throughout the process, building quality is protected during planning and construction and later, during occupation and operations (Preiser and Vischer, 2005).

\section{POST OCCUPANCY EVALUATION}

Post Occupancy Evaluation (POE) has been an active research area for many disciplines. As a result of this, different interpretations of the topic have been provided by researchers. One of the most cited definition was provided by Preiser et al. (1988): Post-occupancy evaluation (POE) is the process of evaluating buildings in a systematic and rigorous manner after they have been built and occupied for some time. As quoted in Hadjri and Crozier (2009), the Royal Institute of British Architects' (RIBA) Research Steering Group defined Post-Occupancy Evaluation from an architectural perspective as "a systematic study of buildings in use to provide architects with information about the performance of their designs and building 
owners and users with guidelines to achieve the best out of what they already have" (RIBA, R.S.G., 1991). Friedman et al. (1978, p.20), on the other hand, stressed the anthropological side and defined POE as an appraisal of the degree to which a designed setting satisfies and supports explicit and implicitly human needs and values of those for whom a building is designed. As Hadjri and Crozier (2009) explain, this anthropocentric perspective is related to the examinations of the effectiveness for human users of occupied design environments.

POE is an important topic for the building industry as it provides an important feedback mechanism for architects about the designed buildings. Due to this importance, it is necessary to conduct a detailed literature review in order to understand where the topic stands for the profession. In contrast with architectural critiques focusing on aesthetics, a POE typically focuses on assessment of client satisfaction and functional 'fit' with a specific space (Zimmerman and Martin, 2001).

The historical context of POE goes back to 1960s. These evaluations have started with one-off case study evaluations in the late 1960s and progressing to system-wide and cross-sectional evaluation efforts in the 1970s and 1980s (Preiser, 2002). From the professional point of view, some regulating bodies have started to be involved in the feedback that POE provides to the building professionals. For example, Cooper (2001) explained the studies of the Royal Institute of British Architects (RIBA) in trying to systematize the profession of architecture in the early 1960s. In 1962, RIBA published 'The Architect and His Office' (RIBA, 1962) and suggested that information and experience on user requirements should be gathered and disseminated. The report has also iterated that the study of buildings in use, from the technical and cost points of view as well as in terms of design, should be carried much further by all types of office.

In later years, the RIBA published its Plan of Work which includes the "feedback stage - Stage $\mathrm{M}^{\prime}$ as the final part. This stage proposed that architects, with their clients, should inspect completed buildings, two to three years after final completion, as 'the most cost effective way of improving service to future clients' (Cooper, 2001). However, Stage M has been dropped from this publication in later additions. Cooper (2001) quoting Lawson states that this may have happened because architects were not paid extra money as this kind of evaluations were seen as part of the architects' normal services to the client.

As a result of the problems of being accepted by the architecture profession, POE was left as an academic research topic for many years. Different disciplines started to be involved in POE research as a result of this disinterest of the architecture community. For example, people working in the field of environmental psychology have got interested in the topic through the development of scientifically established knowledge (Cooper, 2001).

Today, POE has become a mostly discussed research topic in an academic context but it is getting popular in private sector as well (Hadjri and Crozier, 2009). In the UK, POE has gained its credibility again after the publication of Latham (Latham, 1994) and Egan (DTI, 1998) reports. These reports were sponsored by UK Government and Industry following several poorly performing projects and examined how the quality and efficiency in UK construction could be improved. For example, the Egan report (DTI, 1998) indicated that companies do little systematic research on what the 
end-user actually wants, nor do they seek to raise customers' aspirations and educate them to become more discerning. According to Egan, a focus on the customer could be a new driver on achieving a more effective construction industry.

Until now, several researchers have carried out different POE assessments for different building types. These assessments have started with individual building types in 1960s (Preiser, 2002, 9). While POE evaluations carried out in the 1970s and 1980s targeted at performance of buildings, more recent developments in POE have focused on building performance evaluation (BPE) and universal design evaluation (UDE), emphasizing a "more holistic and process-oriented evaluation" (Preiser, 2002, 9). Hospitals (DHFP, 1990; QHRS, 2001; Carthey, 2006; Ornstein et al., 2007) and schools (SEE, 2005; Watson and Thomson, 2005; Mumovic et al., 2009) are two of the mostly examined facilities.

Investments in the tourism sector are getting popular since Turkey has become a major destination for travel and holiday. Investors in this sector need guidelines that can help them direct their resources. There are numerous studies dealing with the convention tourism, however, few of them have focused on the features of convention centres from post occupancy evaluation point of view. Different from the previous studies, this research aims to identify and evaluate the feature priorities of İstanbul Lütfi Kurdar Convention and Exhibition Centre (ICEC) from the perspective of three user groups: Convention organizers, employees and attendees. The following section clarifies the material and method of the study. The paper is concluded with the results of the study.

\section{RESEARCH MATERIAL AND METHOD}

It is vital for professionals in the construction industries to describe the features of end products and measure the users' priorities in order to enable user-oriented design and provide effective investment in the field. In order to carry out a POE, it is necessary to identify the features of convention centres and how users' priorities can be measured; i.e. method of this assessment. This section entails the material and method that cover the subject domain. In the 'research material' section, the features and user groups of convention centres were clarified. On the other hand, the 'research method' part provides the guidelines of the assessment method.

\section{Material}

The study material of this research is considered to be a major convention centre in Turkey in order to understand users' priorities and performance of the building. The selected venue for this study is İstanbul Lütfi Kirdar Convention and Exhibition Centre (ICEC). ICEC has been selected as it has a central location within the city centre and it has a variety of spaces (auditorium, conference hall, meeting room, exhibition hall, ballroom etc.) for congress, exhibition / fair and banquet.

İstanbul Lütfi Kurdar Convention and Exhibition Centre (ICEC) was constructed between the years 1948 and 1952. This facility was firstly designed as a sport and exhibition centre by the architects Vietti Violi, Şinasi Şahingiray and Fazıl Aysu. At the beginning of 1990s, Turkey faced up the need of a convention centre for the upcoming HABITAT organization which was decided to be held in Turkey. Thus, the Lütfi 

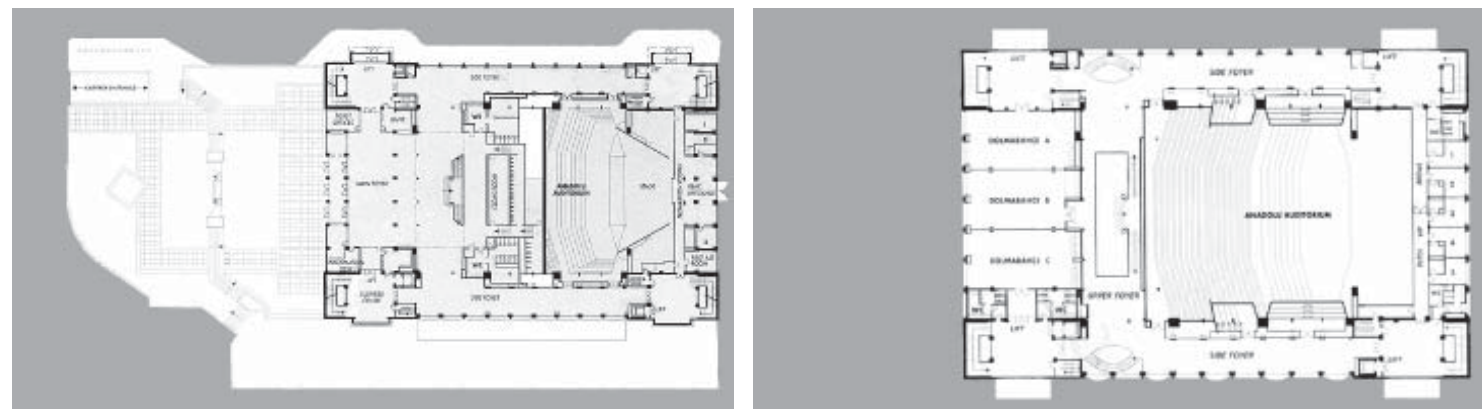

Figure 1a. Ground Floor Plan of the Main Building.

Figure 1b. First Floor Plan of the Main Building.
Figure 2a. Plan of the Rumeli Building.

Figure 2b. Main Meeting Hall.
Kurdar Sport and Exhibition Centre was converted into a convention centre in 1996, currently still the largest convention centre of Turkey.

ICEC has 2 buildings. The main building has an auditorium with 2000 seats and simultaneous translation system in 12 languages. This building also has 4 meeting hall between the capacities of 350 to 650 people. The main building comprises 14 rooms with the capacity of 15 to 50 people for meetings of smaller groups. Except the meeting spaces, it has 5 VIP rooms and a restaurant with the capacity of 300 people.

The second building is named as the Rumeli Building and has started to give service as a trade fair and exhibition centre in 1999. It is one of the first examples of "Exhibition Space Management Supporting Convention Centres" in Turkey. Rumeli Building has $7000 \mathrm{~m}^{2}$ area in two levels and its main hall has a floor area totalling $2100 \mathrm{~m}^{2}$ and 7 meter height. It can be divided into two sound-proof rooms by separators allowing the hall to be used for two different events simultaneously. The lower level of the building gives service for exhibition, fair and banquets with its $3000 \mathrm{~m}^{2}$ area. The Rumeli Building has also a VIP lounge, 5 executive boardrooms, a restaurant with 130 person capacities and a garden with Bosphorus view.

\section{User Groups of the Convention Centre}

Users of a convention centre can be divided into 3 groups: Convention organizers, employees and attendees. The reason of studying with three groups is that each of them experiences the space differently and has different priorities in facility features. These groups are examined below in detail.

- Convention organizers: Meeting planning services are provided by event management and consultancy companies and agencies in Turkey. This group has special importance because they are decision makers in
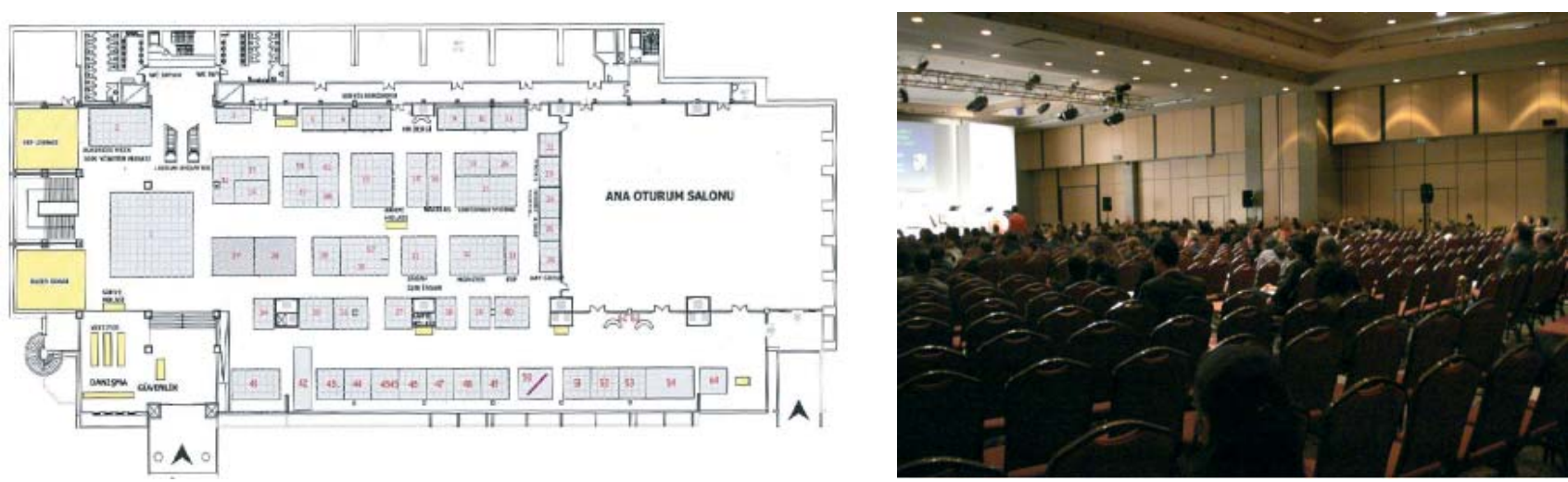
respect of venue selection. In other words, planners' evaluation of a convention centre is very crucial, because they are the people who deal with facility features most while making a venue selection. Some of the studies about convention or meeting industry were conducted from convention organizers' perspective. For instance, the study of Renaghan and Kay (1987) identified facility-related characteristics that convention organizers use to select a facility. Another study, which was conducted by Hinkin and Tracey (2003), identified a set of physical and service-related characteristics of properties that may influence meeting effectiveness. These studies provide valuable information in order to understand the priorities and expectations of convention organizers as a user group of convention centres.

In this study, 56 convention organizers have been contacted by means of e-mail and face-to-face meetings. According to the results, the convention organizers that participated in the study represented age group between the 20 and 60. The largest age group represented in the sample was 21-30 years (55.4\%) and 31-40 years (30.4\%). Almost all of the respondents had university education degree $(96.4 \%)$. The gender distribution between females and males was $42.9 \%$ and $57.1 \%$ respectively.

Nearly two-thirds of the respondents indicated that they worked in convention organizations with the capacity of 250-1000 people. This corresponds to nearly $70 \%$ of the respondents worked in organization of mid-scale conventions and remaining $30 \%$ of them worked in large-scale ones.

- Employees: Employees are the user group which experiences the convention centres most because of spending all working hours in these venues. They are able to observe the deficiencies in a venue consciously, so their evaluation is also valuable in order to identify weakness and strengths of a convention centre.

The employees who participated in this study represented an age group between 20 to 50 years. The largest age group represented in the sample was 21-30 years $(46.7 \%)$ and 31-40 years (40\%). Most of the respondents had a university education degree $(86.7 \%)$. The gender distribution between females and males was $46.7 \%$ and $53.3 \%$ respectively.

- Attendees: Attendees are considered to be the "consumer" among the user groups, while convention organizers and employees are regarded as the "supplier" of the service provided in a convention centre. Attendees can be regarded as a kind of customer according to marketing jargon, because their satisfaction -in parallel with demand- determines the success of the convention. This is why the opinions of attendees are significant in order to assess a convention centre and its features.

Previously, Foxall and Hackett (1994) identified consumers' perception of the success of a location in meeting requirements. Specifically, four main topics were examined: atmosphere, centre environment, physical features and way-finding. Martis and Guenther (2003) have identified some of the features of convention centres under four main topics: way finding, acoustic separation, flexibility and support functions. A recent study of Breiter and Milman (2006) has identified some of the features that attendees would prefer in a convention centre.

This study was conducted with a group of 105 attendees of a convention held at ICEC at February 11-12, 2009. 95 of these attendees have returned 
the questionnaire and 92 of them have been accepted for evaluation. The attendees that participated in the study represented an age group between the 20 and 50. The largest age groups represented in the sample were 3140 years $(48.9 \%)$ and $21-30$ years $(47.8 \%)$. Most of the respondents had a university education degree $(67.4 \%)$. These percentages were directly related to the fact that attendees of this convention were high-educated professionals. The gender distribution between females and males was $58.7 \%$ and $41.3 \%$ respectively.

Most of the respondents have attended to a convention held at a convention centre before. Only $10.9 \%$ of them stated that they have been in a convention for the first time. Almost all of the respondents indicated that they were likely $(48.9 \%)$ or very likely $(47.8 \%)$ to attend a convention at ICEC in the future.

\section{Identifying the Features of the Convention Centre}

The literature review has revealed some of the features of a convention centre from different users' perspectives. Based on these studies, the required features of a convention centre can be analyzed under 3 main titles: Location features, spatial and functional features and technical features.

\section{METHOD}

By understanding the importance and performance aspects of facility features from the users' perspective, large convention centres can be designed and managed to maintain a competitive edge in marketplace. For this purpose, it is important to determine a proper assessment method that measures both users' priorities and sufficiency of facility features from the users' perspective. The selected method for this research and its way of application is mentioned in detail under this title.

\section{Assessment Method: Importance-Performance Analysis (IPA)}

Importance-Performance Analysis (IPA) can be defined as an easilyapplied technique for measuring attribute importance and performance together in order to improve the development of effective marketing programs. The theoretical background for the instrument development was based on the theory originally developed by Martilla and James (1977), where importance and performance of products or services are measured on a set of selected attributes.

According to Martilla and James (1977), firms conducting attribute research to measure consumer acceptance of particular features of their marketing programs frequently encounter problems in translating the results into action. Two problematic factors are:

1. Management may find it difficult to understand the practical significance of research findings expressed in terms of "coefficient of determination" and "levels of stress".

2. The research may have examined only one side of the consumer acceptance question - either attribute importance or attribute performance - rather than both.

Empirical research projects demonstrate that consumer satisfaction is a function of both expectations related to certain important attributes and judgments of attribute performance. In light of these considerations, IPA has been found to be a useful technique for evaluating the elements of a 


\begin{tabular}{|c|c|c|}
\hline $\begin{array}{l}\text { Main titles pertaining to features } \\
\text { of a large convention centre }\end{array}$ & Variables & $\begin{array}{c}\text { Questionnaire } \\
\text { \# for Further } \\
\text { Reference }\end{array}$ \\
\hline \multirow{8}{*}{ Location Features } & Location of the Convention Centre in city & 1 \\
\hline & Silence of the location & 2 \\
\hline & Closeness to accommodation facilities & 3 \\
\hline & Closeness to the catering facilities & 4 \\
\hline & Accessibility by public transport & 5 \\
\hline & Accessibility to airport and bus terminal & 6 \\
\hline & Sufficient parking lot & 7 \\
\hline & Directional road signage to Convention Centre & 8 \\
\hline \multirow{14}{*}{ Spatial and Functional Features } & Capacity of meeting hall & 9 \\
\hline & Size of the foyer & 10 \\
\hline & Sufficient WC and WC for people with disabilities & 11 \\
\hline & Easy accessibility to service spaces from the meeting hall & 12 \\
\hline & Availability of breakout rooms & 13 \\
\hline & Availability of catering units in Convention Centre & 14 \\
\hline & Proximity of catering units to meeting hall & 15 \\
\hline & Placement of the stage & 16 \\
\hline & Seating layout & 17 \\
\hline & Availability of secondary meeting hall & 18 \\
\hline & $\begin{array}{l}\text { Nonexistence of structural elements disturbing the sight angle } \\
\text { in meeting hall }\end{array}$ & 19 \\
\hline & $\begin{array}{l}\text { Easy accessibility of people with disabilities throughout the } \\
\text { Centre }\end{array}$ & 20 \\
\hline & Availability of info desk and bulletin board & 21 \\
\hline & Comfort of the armchairs / chairs in meeting hall & 22 \\
\hline \multirow{13}{*}{ Technical Features } & Efficiency of the illumination system & 23 \\
\hline & Efficiency of ventilating and AC system & 24 \\
\hline & Efficiency of the heating system & 25 \\
\hline & Efficiency of the security system & 26 \\
\hline & Efficiency of the audio-visual system & 27 \\
\hline & Availability of elevator for people with disabilities & 28 \\
\hline & Directional signage within the Convention Centre & 29 \\
\hline & Simultaneous translation system and headphones & 30 \\
\hline & Sufficient public internet access & 31 \\
\hline & Availability of documentation instruments for public use & 32 \\
\hline & Availability of communication instruments for public use & 33 \\
\hline & Efficiency of the generator & 34 \\
\hline & Efficiency of fire warning and extinguishing systems & 35 \\
\hline
\end{tabular}
a relationship between importance and performance and theorized that target levels of performance for particular product attributes should be proportional to the importance of those attributes. In other words, importance is seen as a reflection of the relative value of the various quality attributes to users (O'Neill et al., 2001). According to Barsky (1995), lower importance ratings are likely to play a lesser role in affecting overall perceptions, while higher importance ratings are likely to play a more critical role in determining user satisfaction. The objective is to identify which attributes, or combinations of the attributes are more influential on users' behavior and which have less impact (O'Neill et al., 2001). Lovelock et al. $(1998,150)$ stated that IPA is an especially useful management tool to 
"direct scarce resources to areas where performance improvement is likely to have the most effect on overall user satisfaction". It also has the benefit of pinpointing which service attributes should be maintained at present levels and "those on which significant improvement will have little impact" (Lovelock et al., 1998, 150).

The IPA conceptually rests on multi-attribute models. This technique identifies strengths and weaknesses of an offering in terms of two criteria that users use in making a choice. One criterion is the relative importance of attributes. The other is users' evaluation of the offering in terms of those attributes. A particular application of the technique starts with an identification of the attributes that are relevant to the choice situation investigated. The list of attributes can be developed after surveying the relevant literature and / or conducting focus group interviews. Moreover, a set of attributes pertaining to a particular service (or goods) are evaluated on the basis of how important each is to the user, and how the service or goods is perceived to be performing relative to each attribute. This evaluation is typically accomplished by surveying a sample of users. After determining those attributes that are worthy of subsequent examination, users are asked two questions. One relates to the salience of the attributes and the other to the supplier's own performance in terms of delivery of these attributes. Importance is typically measured prior to the actual consumption experience and performance is measured after the experience has been completed. Results are typically presented on a two-dimensional grid which consists of vertical and horizontal axes scaling the importance and performance of mean values both importance and performance scores (Byeong-Yong and Oh, 2001). By using a central tendency e.g. mean, median or a rank-order measure, the attribute importance and performance scores are ordered and classified into high or low categories; then by pairing these two sets of rankings, each attribute is placed into one of the four quadrants of the importance performance grid (Crompton and Duray, 1985). Mean performance and importance scores are used as coordinates for plotting individual attributes on a two-dimensional matrix as shown in Figure 3. This matrix is used to prescribe prioritization of attributes for improvement and can provide guidance for strategy formulation (Kitcharoen, 2004).

The Importance-Performance Analysis (IPA) has been applied in a number of settings with relatively little modification in form. For example; Chon et al. (1988) applied IPA for the visitors Bureau of Norfolk, Virginia. Nitse and Bush (1993) used IPA to compare preconceptions of dental practices. As a tool, IPA has gained popularity among hospitality and tourism researchers

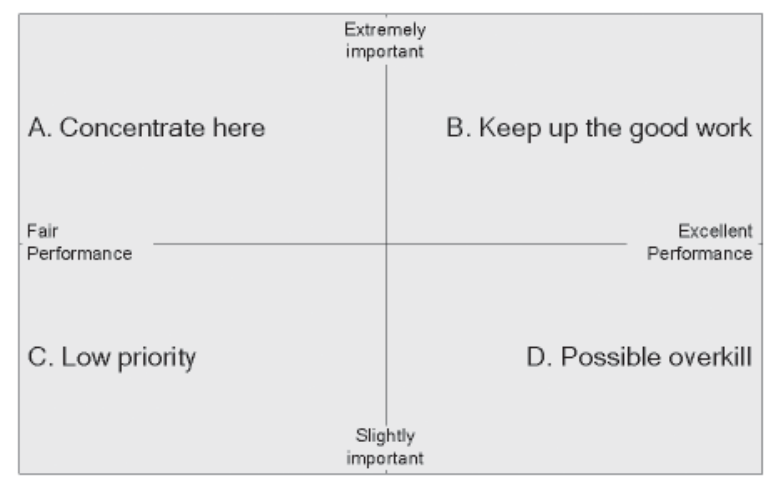


for its simplicity and ease of application. Recently, researchers have suggested an approach to tourism destination competitiveness that goes beyond conventional destination attributes to conclude, in addition, generic business factors of competitiveness. For instance, Enright and Newton (2004) used IPA to compare the factors pertaining to the competitiveness of both the destination's attractions and its tourism industry in Hong Kong. Although, there are some studies regarding to importance-performance analysis of convention industry or destination selection, only a few of them have applied IPA on convention venues.

\section{Development of the Questionnaire and Data Collection}

In order to start the data collection stage, a questionnaire has been prepared based on the identified features presented in Table 1. Based on the questionnaire framework, it has been considered that there would be difference in the assessment of different user groups, i.e. attendees, organizers and employees. Thus, the results of the questionnaires have been evaluated separately for different groups. Respondents have been asked to indicate the level of 35 variables pertaining to facility features provided by a large convention centre. The questionnaire also includes items pertaining to attendance to conventions in past, likelihood to attend future conventions and demographic characteristics of users. The variables of demographic characteristics include gender, age and education level and asked to all user groups. Some variables have been used interchangeably depending on the user group. For instance, questions 34 and 35 have been asked only to organizer and employee groups, because attendees might have no medium to assess the efficiency of these technical features in that limited time. The participants have been asked to rate the level of importance of facility features on a 1-5 scale, when 1 represent "unimportant" and 5 represent "very important". The respondents have been also asked to rate the perceived performance or actual experience with these facility features at the convention centre, where 1 represent "poor experience" and 5 represent "excellent experience".

The questionnaire has been distributed to the attendees of a two-day event which was conducted in İstanbul Lütfi Kurdar Convention and Exhibition Centre (ICEC) at February 11-12, 2009. The convention was held in RumeliA Hall of ICEC which has seating layout in theatre style. Besides the main hall, a seminar room was used for smaller group meetings and foyer of the Rumeli Building was arranged with fair-stands of the firms.

The questionnaire was applied in three main phases. In the first day, the questionnaire has been distributed to 15 employees of the convention centre who deal with convention organizations. The questionnaire has been applied to attendees in the second day of the organization, in contemplation of that attendees would experience the venue more than the first day. The questionnaire was distributed in two coffee-breaks of the second day totally in 80-minute duration. The capacity of the organization was nearly 500 people and questionnaires have been distributed to 95 of them (\%19 of the attendees). Finally, the questionnaire has been distributed to 4 convention organization companies in Ankara and 2 companies in İstanbul. It applied on totally 56 organizers. Questionnaires have been supplied to companies by way of e-mails and face-to-face meetings.

The collected data were examined by plotting the mean ratings of for importance and performance on a two-dimensional grid to produce a 
four-quadrant matrix (Importance-Performance Analysis Framework) that identifies areas needing improvement.

\section{RESULTS OF THE STUDY}

This section includes the results of the questionnaire distributed to three groups of users. The responses of each user groups related to the level of importance and performance of the facility features of the convention centre were highlighted.

\section{Assessment of Facility Features from the Perspective of Convention Organizers}

The convention organizers were asked to rate the level of importance of 35 facility features on a 1-5 scale, when 1 represented "unimportant" and 5 represented "very important". The respondents were also asked to rate the perceived performance, or actual experience, of these facility features at the ICEC, where 1 represented "poor experience" and 5 represented "excellent experience".

The results of the survey are depicted in Appendix A as Table 4. The results indicate that capacity of the meeting hall was perceived to be most important aspect of the facility (mean: 4.84), followed by efficiency of heating system (mean: 4.82) and ventilating-air conditioning system (mean: 4.79). The other two important aspects were stated by organizers as location of convention centre in the city (mean: 4.73) and nonexistence of structural elements disturbing the sight angle in meeting hall (mean: 4.69). The findings revealed that closeness of the convention centre to the catering facilities (mean: 3.72), availability of communication instruments for public use (mean: 3.73 ) and availability of documentation instrument for public use (mean: 3.75) were the least important features of the convention facility perceived by convention organizers. These were followed by proximity of catering units to the meeting hall (means: 3.77 ) and simultaneous translation system and headphones (mean: 3.80) as being less important features. As far as performance of these features at the İstanbul Lütfi Kırdar Convention and Exhibition Centre (ICEC), the highest scores were attributed to location of ICEC in the city (mean: 4.64), size of the foyer (mean: 4.45) and capacity of the meeting hall (mean: 4.43). Convention organizers were also satisfied with closeness of the ICEC to

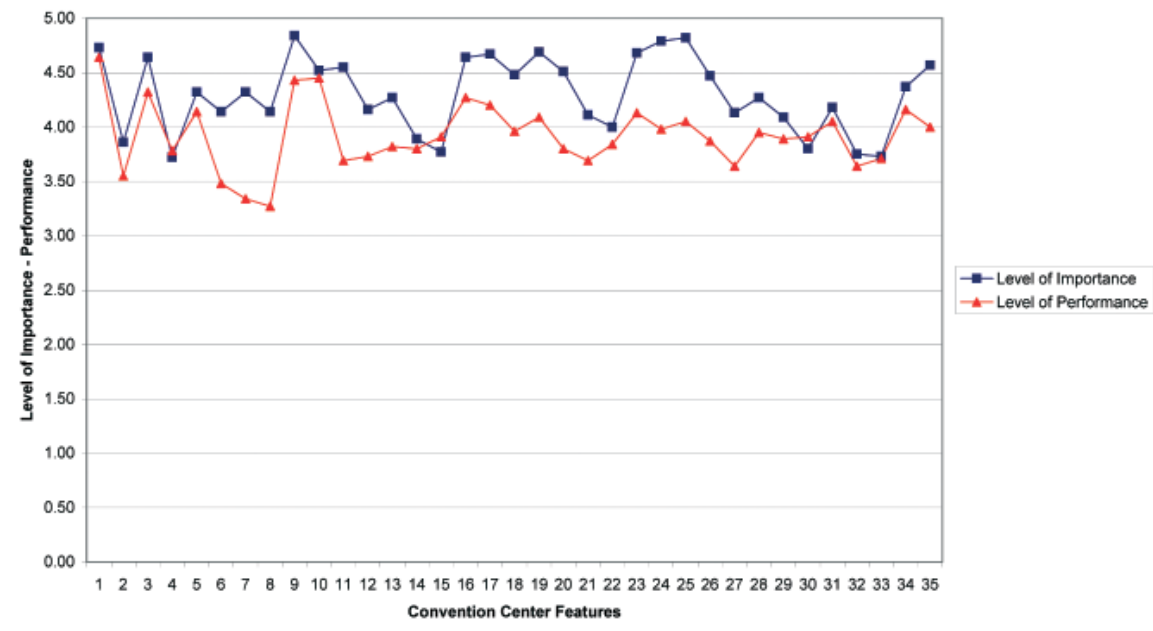


the accommodation facilities (mean: 4.32) and placement of the stage in the meeting hall (mean: 4.27). On the other hand, the lowest scores of ICEC's performance were attributed to directional road signage to the convention centre (mean: 3.27), sufficient parking lot (mean: 3.34 ), accessibility to airport and bus terminal (mean: 3.48 ) and silence of the location (mean: 3.55).

A visual summary of importance and performance results of the convention centre's facility features gaps is illustrated in Figure 4.

\section{Assessment of Facility Features from the Perspective of Employees}

As applied to convention organizers, the employees of ICEC were also asked to evaluate 35 facility features of the convention centre. Each feature was evaluated with regard to level of importance on a 1-5 scale, when 1 represented "unimportant" and 5 represented "very important". The respondents were also asked to rate the perceived performance of the features, where 1 represented "poor experience" and 5 represented "excellent experience".

The results of the survey are depicted in Appendix A as Table 5. The results indicated that efficiency of ventilating and air-conditioning system was perceived to be the most important aspect of the facility (mean: 4.73), followed by efficiency of the audio-visual system (mean: 4.67). Succeeding three aspects; i.e. efficiency of the heating system, availability of elevator for people with disabilities and efficiency of fire warning and extinguishing system, have the same importance level (mean: 4.60) according to employees. The findings revealed that proximity of catering units to the meeting hall (mean: 3.73), availability of communication instruments for the public use (mean: 3.80) and silence of the location (mean: 3.87) were the least important features of the convention facility perceived by employees. These were followed by closeness of the convention centre to the catering facilities, accessibility to airport and bus terminal and availability of secondary meeting hall, as being less important features (mean: 3.93). As far as performance of these features at the ICEC, the highest scores were attributed to the closeness of the centre to accommodation facilities and its location in the city (mean: 4.73). Employees were also satisfied with the availability of secondary meeting hall for smaller group meetings and nonexistence of structural elements disturbing the sight angle in the meeting hall (mean: 4.53). On the other hand, the lowest scores of ICEC's performance were attributed to sufficient parking lot (mean: 3.13), directional road signage to the centre (mean: 3.27 ), availability of catering units in convention centre (mean: 3.47 ), accessibility to airport and bus terminal (mean: 3.73 ) and proximity of catering units to the meeting hall (mean: 3.73).

A visual summary of importance and performance results of facility features gaps from employees' perspective is illustrated in Figure 5.

\section{Assessment of Facility Features from the Perspective of Attendees}

As applied to the first two user groups, the attendees of the convention in ICEC were also asked to evaluate 33 facility features of the convention centre with regard to the level of importance and performance on a 1-5 scale. Differently from the other two groups, attendees were not required to assess two technical features, i.e. efficiency of generator and fire warning and extinguishing system. 1 represented "unimportant" and 5 represented "very important" for evaluation of importance level, where 1 represented 
Figure 5. Levels of Importance versus Performance from Employees Perspective.

Figure 6. Levels of Importance versus Performance from Attendees' Perspective.
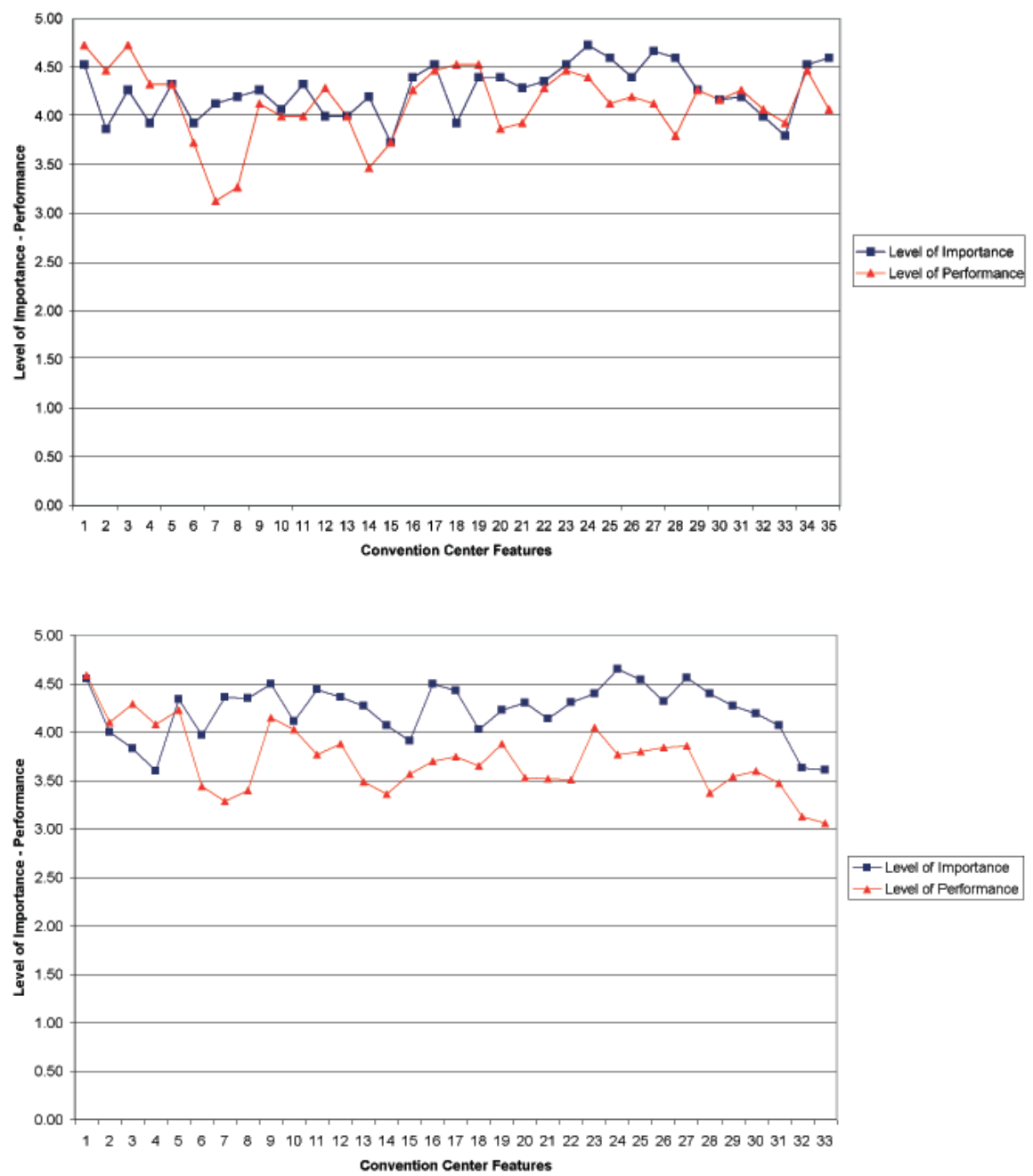

"poor experience" and 5 represented "excellent experience" for evaluation of performance.

The results of the survey are depicted in Appendix A as Table 5. The results indicated that efficiency of ventilating and air-conditioning system was perceived to be most important aspect of the facility (mean: 4.65), followed by efficiency of the audio-visual system (mean: 4.56), location of the convention centre in the city (mean: 4.55) and capacity of the meeting hall (mean: 4.54). Succeeding two aspects; i.e. efficiency of the heating system and placement of the stage in the meeting hall, have the same importance level according to the attendees (mean: 4.50). The findings revealed that closeness of the convention centre to the catering facilities (mean: 3.60), availability of communication instruments (mean: 3.61) and documentation instruments for the public use (mean: 3.63) were the least important features of the convention facility perceived by the attendees. These were followed by closeness of the centre to the accommodation facilities (mean: 3.93) and proximity of catering units to the meeting hall, as being less important features (mean: 3.93). As far as performance of these features at the ICEC, the highest scores were attributed to the location of the convention centre in the city (mean: 4.59), closeness of the centre to the accommodation facilities (mean: 4.29) and accessibility by means of 


\begin{tabular}{|l|c|c|c|c|c|c|c|c|}
\cline { 2 - 9 } \multicolumn{1}{c|}{} & \multicolumn{4}{c|}{ Importance } & \multicolumn{4}{c|}{ Performance } \\
\cline { 2 - 9 } \multicolumn{1}{c|}{} & Overall & Location & Spatial & Technical & Overall & Location & Spatial & Technical \\
\hline Convention organizers & $\mathbf{4 . 3 0}$ & 4.23 & 4.36 & 4.28 & 3.92 & 3.82 & 3.98 & 3.92 \\
\hline Employees & $\mathbf{4 . 2 6}$ & 4.15 & 4.21 & 4.39 & $\mathbf{4 . 1 3}$ & 4.09 & 4.11 & 4.18 \\
\hline Attendees & $\mathbf{4 . 2 2}$ & 4.13 & 4.26 & 4.24 & 3.72 & 3.93 & 3.70 & 3.59 \\
\hline
\end{tabular}

Table 2. Overall means of importance and performance scores of users. public transportation (mean: 4.23). Attendees were also satisfied with the capacity of meeting hall (mean: 4.15) and silence of the location of ICEC (mean: 4.10). On the other hand, the lowest scores of ICEC's performance were attributed to availability of communication instruments (mean: 3.06) and documentation instruments for the public use (mean: 3.13), sufficient parking lot (mean: 3.29), availability of catering units in the convention centre (mean: 3.36 ) and availability of elevator for people with disabilities (mean: 3.37).

A visual summary of importance and performance results of facility features gaps from attendees' perspective is illustrated in Figure 6.

\section{Data Plotting of Users' Scores with IPA Matrix}

A standard approach adopted by IPA is to combine measures of importance and performance into a two dimensional grid so as to ease data interpretation and elicit suggestions for action. In forming this grid, the scores of the "importance" and "performance" perception of the user groups are reflected into a two dimensional matrix. The evaluations of each facility features are depicted on graphs whose axes are composed of values between 0 and 5 (The axis of Figure 7, 8, 9 are depicted with the

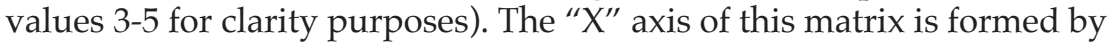
the values of 'performance' and the " $Y$ " axis of this matrix is formed by the values of 'importance'. Next, the overall mean scores of each user group for each category (location, spatial, technical) are calculated. These values are available in Table 2. Figure 7, 8, 9 present overall mean scores of the user groups graphically (represented by red color dashed lines parallel to $\mathrm{X}$ and $\mathrm{Y}$ axis).

The "quadrants" available in these figures can be used to generate suggestions. Quadrant $A$, which includes high importance and high performance level, identifies the attributes that the Convention Centre should strive to maintain or "keep up the good work". Quadrant B, which includes factors that are high in importance but low in performance, identifies critical areas for improvement where decision makers are recommended to "concentrate here". Quadrant C identifies areas of low priority, including factors in which the convention centre is not particularly successful, or satisfactory, but which are low in importance also. Quadrant $D$ includes factors that are low in importance but high in performance, and thus identifies area as wasted effort or "possible overkill". Figure 7, 8, 9 give the distribution of each facility features onto two-dimensional grid according to assessment of each user group. In this study, it is focused on features in Quadrant A and B, which include high importance level. Numeric variables in Figure 7, 8, 9 correspond to the facility features as listed in Table 1. Features of the Convention Centre. 


\section{CONVENTION ORGANIZERS' IPA MATRIX}

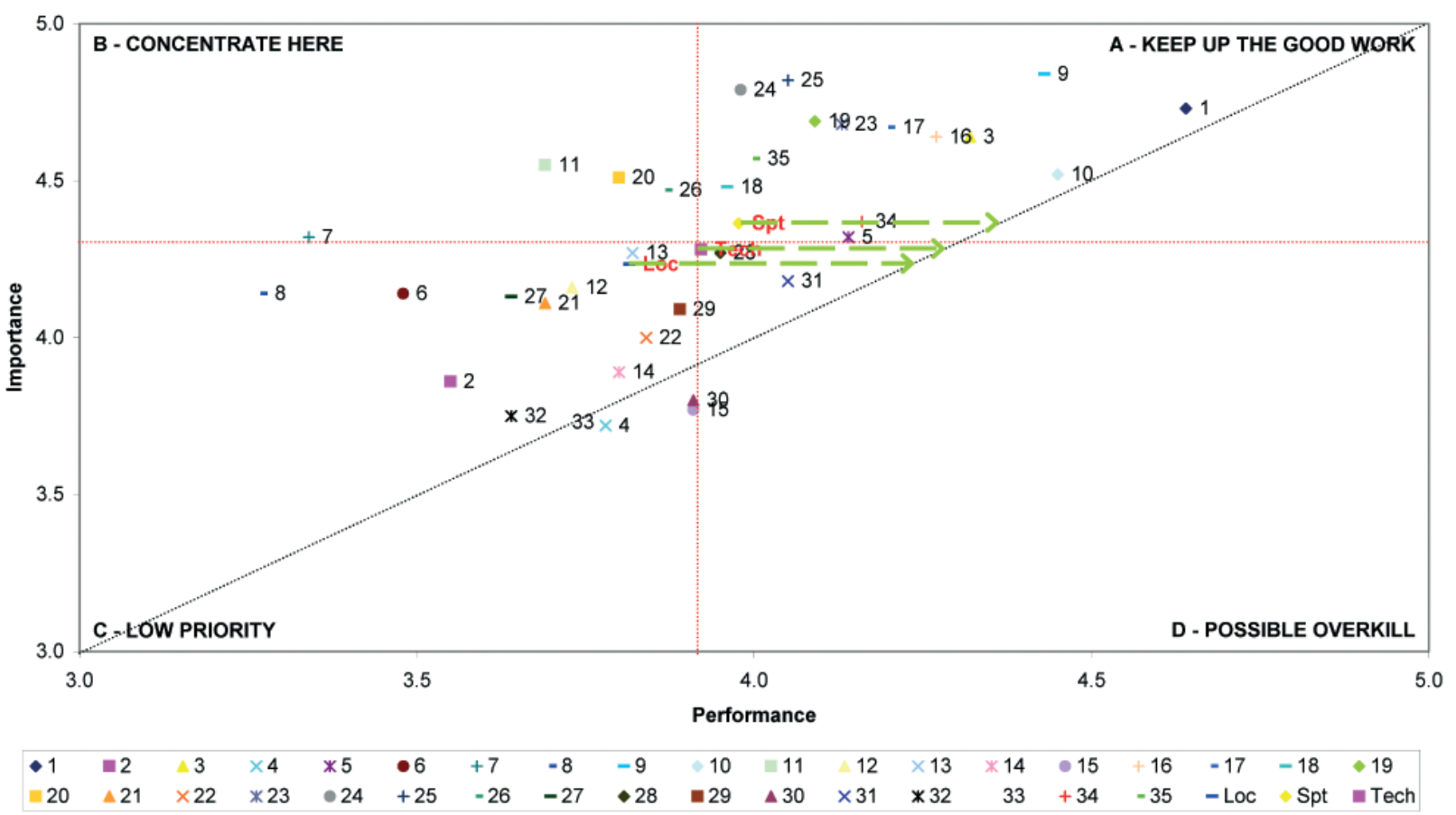

Figure 7. Convention Organizers' Scores on the IPA Matrix.

\section{EMPLOYEES' IPA MATRIX}

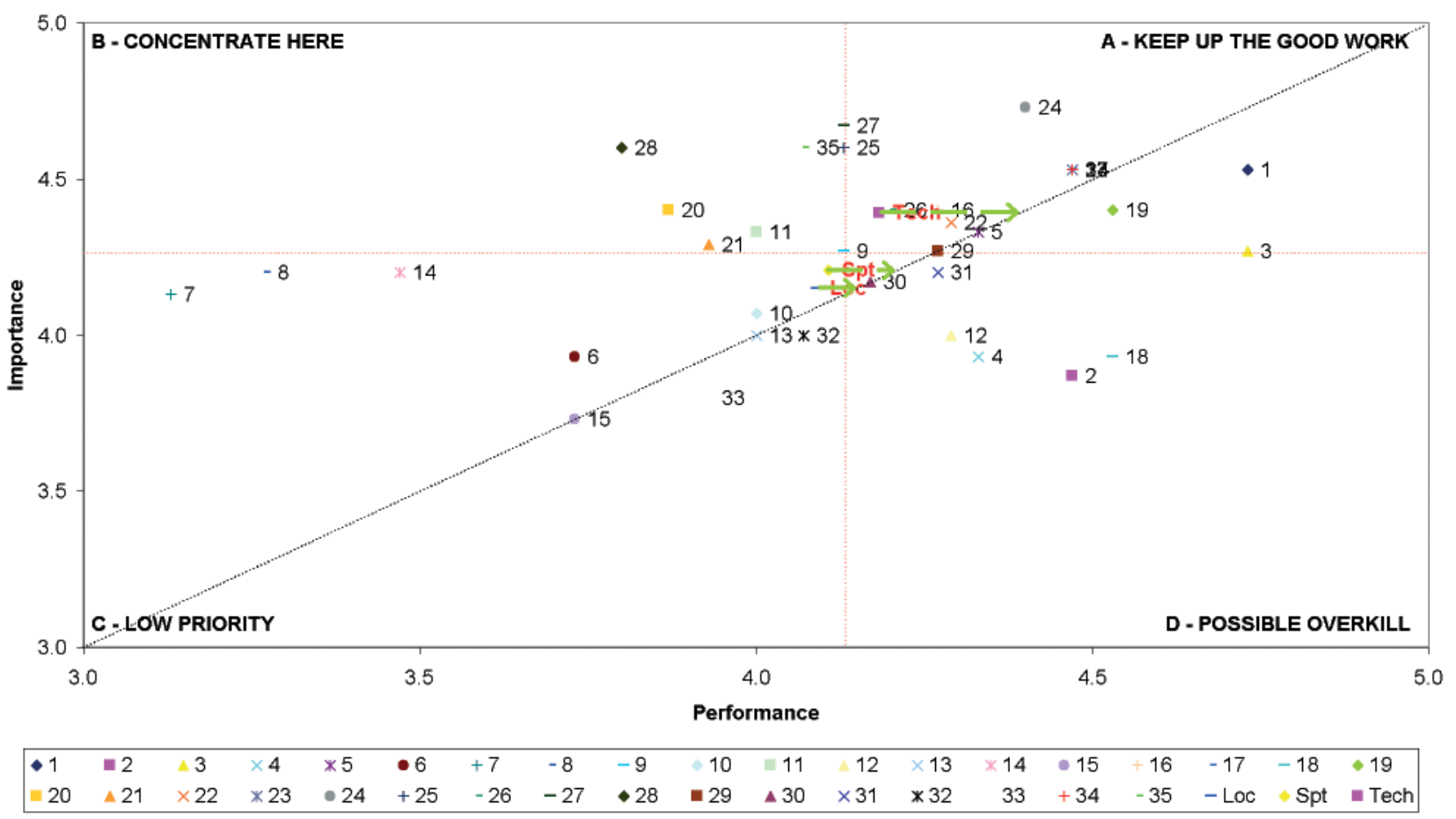

Figure 8. Employees' Scores on the IPA 


\section{ATTENDEES' IPA MATRIX}

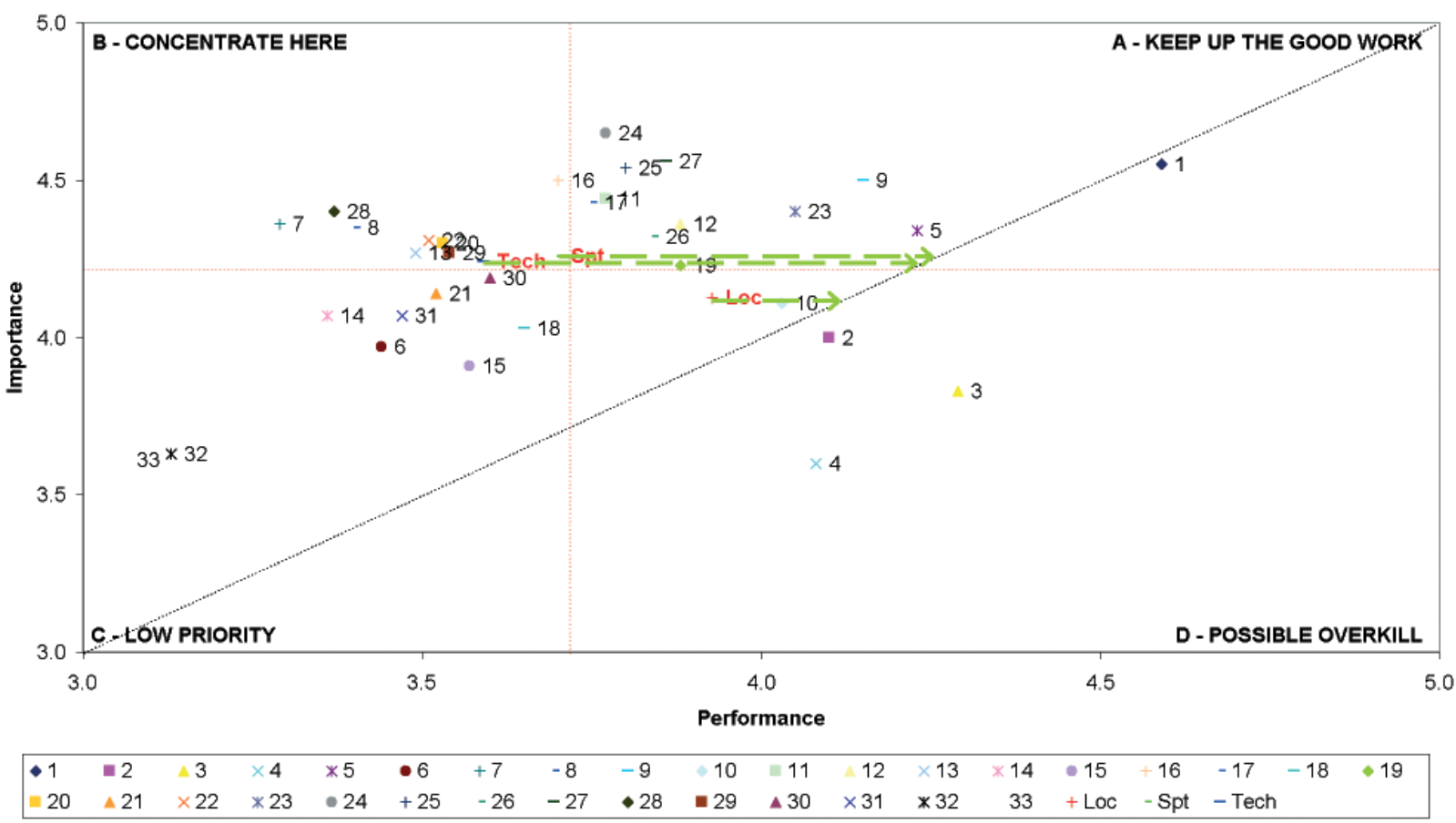

A close examination of Figure 7, 8 and 9 reveal that 25 out of 35 facility features were perceived as important on average by any user group. However, among these 25 items, 12 facility features were perceived as 'important' by three user groups commonly. These features, which were given importance above average by all user groups, are listed as follows:

1. Location of the convention centre in the city

5. Accessibility by means of public transportation

9. Capacity of meeting hall

11. Sufficient number of restroom and restroom for people with disabilities

16. Placement of the stage

17. Seating layout

19. Nonexistence of structural elements, such as columns etc., disturbing the angle of sight in the meeting hall

20. Easy accessibility of people with disabilities to spaces throughout the centre

23. Efficiency of the illumination system

24. Efficiency of the ventilating and air-conditioning system

25. Efficiency of the heating system

26. Efficiency of the security system. 


\section{Examination of Facility Performance}

Figure 7, 8 and 9 indicate that the ICEC building provides above the average performance on 25 out of 35 facility features by any user group. However, it is seen that each of the user groups commonly determine the venue very satisfactory in terms of 9 aspects. These 9 satisfactory performance features of ICEC are listed as follows:

1. Location of the convention centre in the city

3. Closeness of the centre to the accommodation facilities

5. Accessibility by means of public transportation

9. Capacity of meeting hall

17. Seating layout

19. Nonexistence of structural elements, such as columns etc., disturbing the angle of sight in the meeting hall

23. Efficiency of the illumination system

24. Efficiency of the ventilating and air-conditioning system

25. Efficiency of the heating system.

Despite its satisfactory aspects, ICEC has some facility features with low satisfactory level. Facility features that were commonly determined as unsatisfactory by all user groups are listed as follows:

6 .Accessibility to airport and bus terminal from the convention centre

7. Sufficient parking lot

8. Directional road signage to the convention centre

13. Availability of breakout rooms

14. Availability of catering units in the convention centre

15. Proximity of catering units to the meeting hall

20. Easy accessibility of people with disabilities to spaces throughout the centre

21. Availability of information desk and bulletin board

32. Availability of documentation instruments (printer, photocopy machine etc.) for public use

33. Availability of communication instrument (telephone-fax etc.) for public use.

While examining the list of facility features related with performance scores, it should be kept in mind that they are composed regardless of the importance level of these features. Among these 10 facility features, some of them are regarded as 'important', while some of them are regarded as 'unimportant'. When high-importance level is taken into account, we should focus on "Quadrant A: Keep up the Good Work" and "Quadrant B: Concentrate Here". The highlighted facility features are shown in Figure 10 and Figure 11.

According to these diagrams, all user groups commonly determines that ICEC is successful in terms of its 'location in İstanbul, accessibility by means of public transportation, capacity of meeting hall, seating layouts of meeting hall, nonexistence of structural elements disturbing the sight 
Figure 10. Facility Features in "Quadrant A: Keep up the Good Work".
Figure 11. Facility Features in "Quadrant B: Concentrate Here".
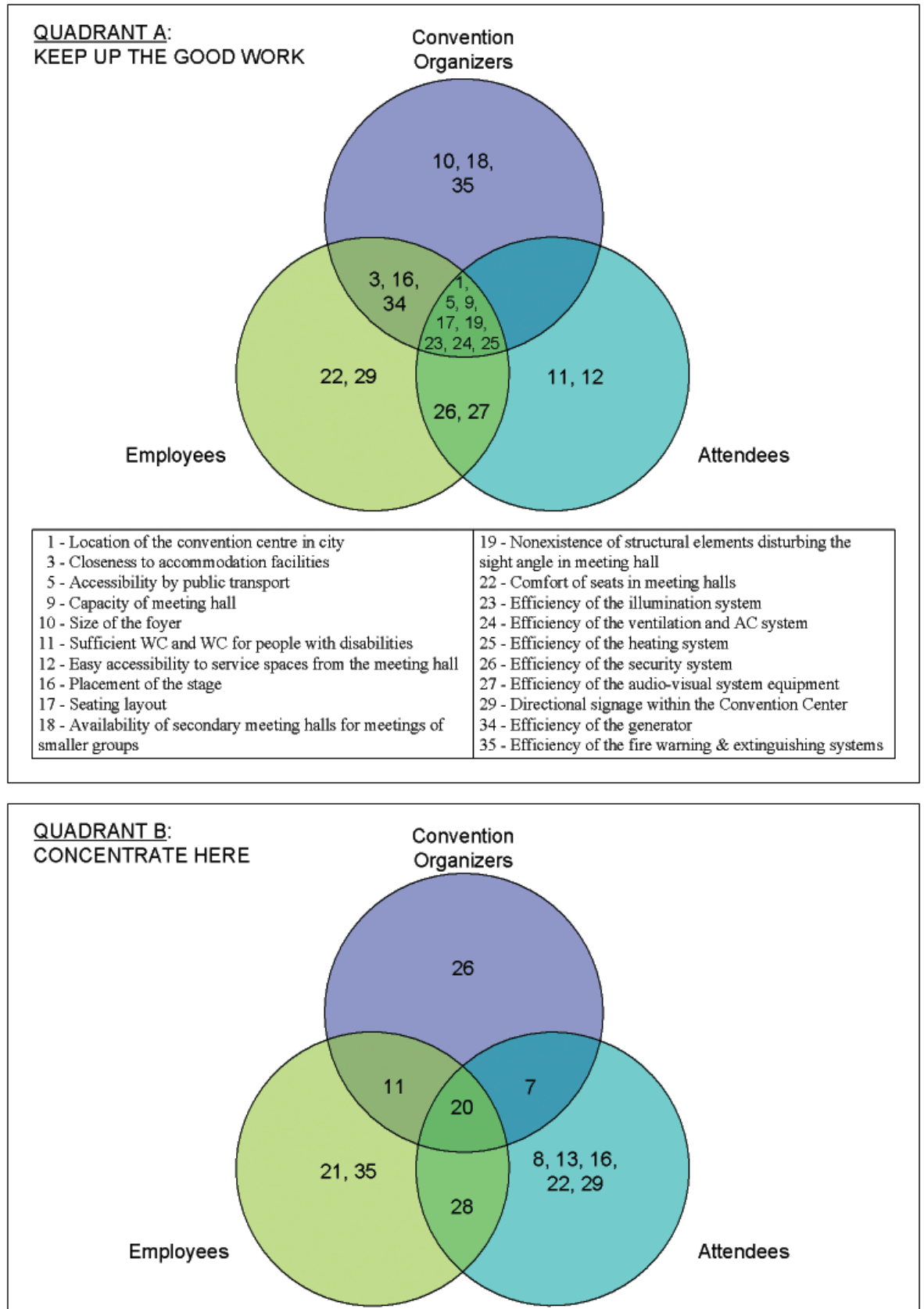

7 - Sufficient parking lot

8 - Directional road signage to Convention Centre

11 - Sufficient number of WC and WC for people with disabilities

13 - Availability of breakout rooms

16 - Placement of the stage

20 - Easy accessibility of people with disabilities to spaces throughout the Center
21 - Availability of info desk \& bulletin board 22 - Comfort of the seats in meeting halls 26 - Efficiency of the security system 28 - Availability of elevator for people with disabilities 35 - Efficiency of the fire warning \& fire-extinguishing systems angle in meeting hall and efficiency of HVAC and illumination systems'. However, all user groups commonly determine that ICEC should focus on improving the features 'of easy accessibility of people with disabilities to spaces throughout the Centre.' 


\section{Performance Improvement Gaps}

The IPA matrices were further analysed in order identify which sub-groups of the facility features would be appropriate to allocate resources. For this, first, the importance - performance gaps for each facility sub-group were calculated for each user group. This has been depicted in the following table.

\begin{tabular}{|l|c|c|c|c|}
\cline { 2 - 5 } \multicolumn{1}{c|}{} & \multicolumn{4}{c|}{ Importance - Performance Gaps } \\
\hline Convention organizers & Overall & Location & Spatial & Technical \\
\hline Employees & 0.38 & 0.41 & 0.38 & 0.36 \\
\hline Attendees & 0.13 & 0.06 & 0.10 & 0.21 \\
\hline
\end{tabular}

Next, the IPA matrices were introduced an upward sloping, $45^{\circ}$ line to distinguish regions of differing priorities. This line is named as the iso-rating or iso-priority line, where importance equals performance and depicted as a black-coloured dashed line in the figures (Because of the unequal intervals of the $\mathrm{X}$ and $\mathrm{Y}$ axes, the lines in the figures do not have a $45^{\circ}$ slope). Next, the mean values of each feature group were depicted at the IPA matrices for each user group and Figures 7, 8 and 9 were further analyzed to identify the possible improvement areas of the facility sub-feature categories. The performance gaps, which are the differences between the importance and the performance values, were indicated with green coloured dashed lines in the figures. These dashed lines indicate that the performance value of the value facility sub-features need to be moved right in order to have a value which is at least equal to the importance value.

The analyses of performance gaps reveal the following points:

- Attendees are the least satisfied user group in terms of the spatial and technical features. More resources need to be allocated to the selected sub-features of these groups to improve the satisfaction level of the conference attendees.

- Convention organizers consider the location aspect of the facility as the least satisfactory item.

- Employees are the most satisfied user group in terms of the three facility sub-features groups.

\section{CONCLUSIONS}

This study was an attempt to provide a POE of a large convention centre. In order to achieve this, three user groups, i.e. attendees of conventions, convention organizers and employees of the venue, have been taken into consideration and the study have been conducted among these user groups. The importance assigned by the users were compared with the performance value and results were presented with a two dimensional matrix, which is called the Importance - Performance Analysis (IPA) Matrix. Moreover, some similarities and differences in expectations among these groups also have been drawn attention in this evaluation.

To elaborate on all three groups' preferences, it has been identified that all three groups put special importance on spatial and functional features associated with meeting hall (capacity, placement of the stage, seating 
layout, nonexistence of structural elements disturbing the sight angle). All of three user groups underlined the importance of some location features commonly (location in the city centre and accessibility by public transport). These three groups were also commonly sensitive to the items related with people with disabilities (easy accessibility of people with disabilities throughout the centre and availability of elevator for them). Finally, all user groups indicated that the efficiency of the technical features (illumination, HVAC, heating and security systems) was important in the Conference Centre.

The case study that is conducted by the application of the IPA method on Lütfi Kırdar Convention and Exhibition Centre provides some important results in order to understand the strengths and weaknesses of the venue, as being an important convention centre of Turkey. The results display that ICEC perform well in the areas of its location in İstanbul, accessibility by means of public transportation, capacity of meeting hall, seating layouts of meeting hall, nonexistence of structural elements disturbing the sight angle in meeting hall and efficiency of HVAC and illumination systems. These well performing factors were determined commonly by all user groups. On the other hand, all user groups commonly state that ICEC should focus on improving the feature of easy accessibility of people with disabilities to the spaces throughout the centre.

These performance gaps should alert decision makers -such as architects, facility managers and investors- to direct their priorities to the needs of the users. Since many of the conventions in the convention centre are annual or rotating events, improved experiences for users -particularly for convention organizers and attendees- in these venues should lead these people to be more likely to return for future events held there. As the expansion of existing convention venues and the development of new facilities continue all around the world, convention centres need to find ways to distinguish themselves and present satisfactory experience for users. The convention centre in this study, ICEC, obviously had some strength in terms of its performance on important feature variables, but it can still improve the value it provides to its users.

The information presented in this study about the identification of facility features of convention centres and suggested method for evaluating the users' perception of these features can help architects and designers in order to make effective and user-oriented planning in the design phase of projects. This can also be useful for facility managers in order to determine how to allocate the resources to create better experiences in buildings and share the information with building's investors who also have a vested interest in the continued success of the convention centre. Other constituencies associated with the meeting industry that market convention centres can also make benefit of the results of this study. While the study was conducted in a single convention centre, inferences could be drawn to other facilities in Turkey or elsewhere. The suggested method, the importance-performance analysis, can be developed in order to evaluate other types of facilities, such as hotels, hospitals etc. for the future studies. 


\section{REFERENCES}

BARSKY, J. D. (1995) World- Class Customer Satisfaction, Irwin Publishing, Chicago.

BREITER, D. and MILMAN, A. (2006) “Attendees' Needs and Service Priorities in a Large Convention Centre: Application of the Importance-Performance Theory", Tourism Management, v: 27, n: 6; 1364-70.

BYEONG-YOUNG, K. and OH, M. (2001) “An Extended Application of Importance-Performance Analysis", Journal of Hospitality \& Leisure Marketing, v: 9, n: 3-4; 107-25.

CARTHEY, J. (2006) Post Occupancy Evaluation: Development of a Standardised Methodology for Australian Health Projects, The International Journal of Construction Management, July; 57-74.

CHON, K.S., WEAWER, P.A. and KIM, C.Y. (1988) Marketing Your Community: Image Analysis in Norfolk, Cornell Hotel and Restaurant Administration Quarterly, v: 31, n: 4; 31-7.

COOPER, I. (2001) Post-Occupancy Evaluation - Where are You? Building Research and Information, v: 29, n: 2; 158-63.

CROMPTON, J.L., and DURAY, N.A. (1985) An Investigation of the Relative Efficacy of Four Alternative Approaches to ImportancePerformance Analysis, Journal of the Academy of Marketing Science, v:13, n; 4; 69-80.

DHFP (1990) Indian Health Service Hospital Browning Montana Facility Post Occupancy Evaluation, Division of Health Facilities Planning, Office of Resource Management, Office of Management.

DTI (1998) Rethinking Construction: The Report of the Construction Task Force, Department of Trade and Industry.

ENRIGHT, M.J. and NEWTON, J. (2004) Tourism Destination Competitiveness: A Quantitative Approach, Tourism Management, v: 25, n: 6; 777-88.

FOXALL, G. and HACKETT, P. (1994) Consumer Satisfaction with Birmingham's International Convention Centre, The Service Industries Journal, v: 14, n: 3; 369-80.

FRIEDMAN, A., ZIMRING, C., ZUBE, C. (1978) Environmental Design Evaluation, Plenum, New York, NY.

HADJRI, K. and CROZIER, C. (2009) Post-Occupancy Evaluation: Purpose, Benefits and Barriers, Facilities, v: 27, n: 1-2; 21-33.

HINKIN, T.R. and TRACEY, J.B. (2003) The Service Imperative: Factors Driving Meeting Effectiveness, Cornell Hotel and Restaurant Administration Quarterly, v: 44, n: 5-6; 17-27.

KITCHAROEN, K. (2004) “The Importance-Performance Analysis of Service Quality in Administrative Departments of Private Universities in Thailand", ABAC Journal, v: 24, n: 3; 20-46.

LATHAM, Sir M. (1994) Constructing the Team: The Latham Report, HMSO, London.

LOVELOCK, C., PATTERSON, P.G., WALKER, R.H. (1998), Services Marketing, Prentice-Hall, Sydney. 
MARTILLA, J.A. and JAMES, J.C. (1977) Importance - Performance Analysis, Journal of Marketing, January, v: 24, n: 1; 77-9.

MARTIS, J.B. and GUENTHER, A. (2003) The Qwest for Excellence: A Post Occupancy Evaluation of Qwest Centre Omaha, Arch 556 / Arch 456 Term Paper.

MUMOVIC, D., DAVIES, M., RIDLEY, I., ALTAMIRANO-MEDINA, H., ORESZCZYN, T. (2009) A Methodology for Post-Occupancy Evaluation of Ventilation Rates in Schools, Building Services Engineering Research and Technology, v: 30, n: 2; 143-52.

NITSE, P.S. and BUSH, R.P. (1993) An Examination of Retail Dental Practices Versus Private Dental Practices Using an Importance Performance Analysis, Health Marketing Quarterly, v: 11, n: 1-2; 20721.

PEMBEGÜL, T. (2009) Assessment of Convention Centers from Users' Perspective: Application of Importance-Performance Analysis, Unpublished M.Sc. Thesis in Building Science, Middle East Technical University, Ankara.

O'NEILL, M., WRIGHT, C., FITZ, F. (2001) Quality Evaluation in Online Service Environments: An Application of the ImportancePerformance Measurement Technique, Managing Service Quality, v: 11, n: 6; 402-17.

ORNSTEIN, S.W., ONO, R., LOPES, M.E., MONTEIRO, R.Z., GILL, A.A., MACHRY, H.S. (2007) Health Care Architecture in São Paulo, Brazil Evaluating Accessibility and Fire Safety in Large Hospitals" International Journal of Architectural Research, v: 1, n: 1; 13-25.

PREISER, W.F.E., RABINOWITZ, H.Z., WHITE, E.T. (1988) Post-Occupancy Evaluation, Van Nostrand Reinhold, New York.

PREISER, W. (2002) The Evolution of Post-Occupancy Evaluation: Toward Building Performance and Universal Design Evaluation. Learning from Our Buildings: A State-of-the-Practice Summary of Post-Occupancy Evaluation, Federal Facilities Council Technical Report No: 145, National Academy Press, Washington, D.C.; 9-22.

PREISER, W.F.E. and VISCHER, J.C. (2005) The Evolution of Building Performance Evaluation: An Introduction" in W.F.E. Preiser and J.C. Vischer, eds., Assessing Building Performance, First Edition, Elsevier Butterworth-Heinemann, Oxford; 3-14.

QHRS (2001) Royal Children's Hospital Post Occupancy Evaluation, Queensland Health and Royal Children's Hospital Health Service District.

RENAGHAN, L.M. and KAY, M.Z. (1987) What Convention organizers Want: The Conjoint Analysis Approach, Cornell Hotel and Restaurant Administration Quarterly, v: 28, n: 1; 67-76.

RIBA, R.S.G. (1991) A Research Report for the Architectural Profession, in Duffy, F.W., ed., Architectural Knowledge: The Idea of a Profession, E. \& F.N. Spon, London.

Royal Institute of British Architects (1962) The Architect and His Office: A Survey of Organization, Staffing, Quality of Service and Productivity, RIBA, London. 
Alındı: 25.08.2009; Son Metin: 24.03.2010

Anahtar Sözcükler: Kullanım Süreci Değerlendirmesi (KSD); Önem-Performans Analiz Metodu (ÖPA); kültür kongre merkezi.
SEE (2005) Post Occupancy Evaluation - Braes High School, Falkirk, Scottish Executive, Edinburgh.

SLACK, N. (1991) “The Importance-Performance Matrix as a Determinant of Improvement Priority, International Journal of Operations $\mathcal{E}$ Production Management, v: 14, n: 5; 59-75.

WATSON, C. and THOMSON, K. (2005) Bringing Post-Occupancy Evaluation to Schools in Scotland, OECD/PEB Evaluating Quality in Educational Facilities. OECD Publishing; 129-34.

ZIMMERMAN, A. and MARTIN, M. (2001) Post-Occupancy Evaluation: Benefits and Barriers, Building Research and Information, vol. 29, no. 2; 168-74.

\section{MIMARLIK PRATİĞINDE KULLANIM SÜRECİ DEĞERLENDİRMESİ: LÜTFI KIRDAR KONGRE VE SERGI SARAYI ARAŞTIRMASI}

Müşterilerin veya kullanıcıların isteklerine karşılık verebilmek, başarılı binalar tasarlamak ve inşa etmek açısından çok önemlidir. Mimarlar binaların kullanıcılarından geri bildirim alarak daha başarılı binalar tasarlamalı ve ileriki aşamalardaki hataları en aza indirmelidirler. "Kullanım Süreci Değerlendirmesi (KSD)" binaların pozitif ve negatif yönleri hakkında fikir verebilecek önemli bir değerlendirme mekanizmasıdır.

Bu çalışma, İstanbul'daki önemli bir kongre merkezi olan Lütfi Kırdar Uluslararası Kongre ve Sergi Sarayı (ICEC) hakkında bir Kullanım Süreci Değerlendirmesi (KSD) sunmaktadır. Araştırma kapsamında Kongre Merkezleri özellikleri 3 ana başlık altında (konumsal, mekansal, fonksiyonel ve teknik özellikler) incelenmiştir. Daha sonra 3 kullanıcı grubu (konferans düzenleyicileri, merkez çalışanları ve konferans katılımcları) bu ana başlıklar altında yer alan 35 bina özelliğinin önem derecesini ve performasını 1 ve 5 arasında değişen oranlar ile değerlendirmişlerdir. Bu değerlendirmede 1 "daha az önemi” ve "kötü performansı", 5 ise "daha fazla önemi" ve "iyi performansı" göstermektedir.

Seçilen binanın niteliklerini değerlendirmek için Önem-Performans Analiz Metodu (ÖPA) kullanılmıştır. ÖPA metodu, kullanıcıların yaptıkları seçimler sayesinde incelenen vakanın güçlü ve zayıf yönlerini ortaya çıkartır. ÖPA'da ana amaç incelenen vakadaki özelliklerin göreceli öneminin ve bu özelliklerin gösterdiği performansın kullanıcılar tarafından değerlendirilmesidir.

Araştırma sonuçlarına göre 3 kullanıcı grubu da Kongre Merkezi'nin konum, toplu taşıma ile ulaşılabilirlilik, toplantı salonu kapasitesi, oturma düzeni, görüşü engelleyen strüktürel elemanların olmaması, 1şıklandırma, havalandırma ve isıtma sistemlerinin etkin işleyişi konularında başarılı olduğunu belirtmiştir. Diğer yandan Kongre Merkezi'nde engeli olan insanların hareketine olanak verecek düzenlemelerin olmaması eleştiri noktası olmuştur. 
ALİ MURAT TANYER; B.Arch., M.Sc., Ph.D.

Received B.Arch (Hons.) and M.Sc. in Building Science from METU in 1997 and 1999 respectively. In 2005 completed his Ph.D. at University of Salford, U.K. Currently working as Assistant Professor at METU. Main research areas are Construction Informatics, particularly, integrated computer environments; Building Information Models (BIM), simulation, and visualisation. tanyer@metu.edu.tr

TUĞBA PEMBEGÜL; B.Arch., M.Sc.

Received B.Arch. and M.Sc. in Building Science from METU in 2004 and 2009, respectively. Currently working as Culture and Tourism Specialist at the Ministry of Culture and Tourism in Turkey. Main research areas are convention tourism, convention and culture facilities. tpembegul@yahoo.com

Table 4. Convention organizers' perception APPENDIX of facility features at the Convention Centre.

\begin{tabular}{|c|c|c|c|c|c|}
\hline \multirow{2}{*}{ No } & \multirow{2}{*}{ Facility Features } & \multicolumn{2}{|c|}{ Level of Importance } & \multicolumn{2}{|c|}{ Level of Performance } \\
\hline & & Mean & Std.D. & Mean & Std.D. \\
\hline 1 & Location of the Convention Centre in city & 4.73 & 0.56 & 4.64 & 0.55 \\
\hline 2 & Silence of the location & 3.86 & 1.09 & 3.55 & 0.78 \\
\hline 3 & Closeness to accommodation facilities & 4.64 & 0.48 & 4.32 & 0.81 \\
\hline 4 & Closeness to the catering facilities & 3.72 & 0.95 & 3.78 & 0.79 \\
\hline 5 & Accessibility by public transport & 4.32 & 0.79 & 4.14 & 0.65 \\
\hline 6 & Accessibility to airport and bus terminal & 4.14 & 0.99 & 3.48 & 0.91 \\
\hline 7 & Sufficient parking lot & 4.32 & 0.97 & 3.34 & 1.13 \\
\hline 8 & Directional road signage to Convention Centre & 4.14 & 0.86 & 3.27 & 1.27 \\
\hline 9 & Capacity of meeting hall & 4.84 & 0.37 & 4.43 & 0.49 \\
\hline 10 & Size of the foyer & 4.52 & 0.63 & 4.45 & 0.50 \\
\hline 11 & Sufficient WC and WC for people with disabilities & 4.55 & 0.50 & 3.69 & 0.77 \\
\hline 12 & Easy accessibility to service spaces from the meeting hall & 4.16 & 0.63 & 3.73 & 0.75 \\
\hline 13 & Availability of breakout rooms & 4.27 & 0.65 & 3.82 & 0.66 \\
\hline 14 & Availability of catering units in Convention Centre & 3.89 & 0.68 & 3.80 & 0.84 \\
\hline 15 & Proximity of catering units to meeting hall & 3.77 & 0.69 & 3.91 & 0.84 \\
\hline 16 & Placement of the stage & 4.64 & 0.65 & 4.27 & 0.67 \\
\hline 17 & Seating layout & 4.67 & 0.61 & 4.20 & 0.80 \\
\hline 18 & Availability of secondary meeting hall & 4.48 & 0.57 & 3.96 & 1.03 \\
\hline 19 & $\begin{array}{l}\text { Nonexistence of structural elements disturbing the sight angle in } \\
\text { meeting hall }\end{array}$ & 4.69 & 0.50 & 4.09 & 0.86 \\
\hline 20 & Easy accessibility of people with disabilities throughout the Centre & 4.51 & 0.61 & 3.80 & 0.78 \\
\hline 21 & Availability of info desk and bulletin board & 4.11 & 0.73 & 3.69 & 0.78 \\
\hline 22 & Comfort of the armchairs / chairs in meeting hall & 4.00 & 0.85 & 3.84 & 0.91 \\
\hline 23 & Efficiency of the illumination system & 4.68 & 0.54 & 4.13 & 0.83 \\
\hline 24 & Efficiency of ventilating and AC system & 4.79 & 0.49 & 3.98 & 0.92 \\
\hline 25 & Efficiency of the heating system & 4.82 & 0.39 & 4.05 & 0.88 \\
\hline 26 & Efficiency of the security system & 4.47 & 0.63 & 3.87 & 0.82 \\
\hline 27 & Efficiency of the audio-visual system & 4.13 & 1.08 & 3.64 & 1.12 \\
\hline 28 & Availability of elevator for people with disabilities & 4.27 & 0.62 & 3.95 & 0.83 \\
\hline 29 & Directional signage within the Convention Centre & 4.09 & 0.90 & 3.89 & 0.93 \\
\hline 30 & Simultaneous translation system and headphones & 3.80 & 1.25 & 3.91 & 1.01 \\
\hline 31 & Sufficient public internet access & 4.18 & 1.13 & 4.05 & 0.90 \\
\hline 32 & Availability of documentation instruments for public use & 3.75 & 1.13 & 3.64 & 1.07 \\
\hline 33 & Availability of communication instruments for public use & 3.73 & 1.15 & 3.71 & 1.09 \\
\hline 34 & Efficiency of the generator & 4.37 & 0.86 & 4.16 & 0.73 \\
\hline \multirow[t]{2}{*}{35} & Efficiency of fire warning and extinguishing systems & 4.57 & 0.79 & 4.00 & 0.91 \\
\hline & Mean & 4.30 & & 3.92 & \\
\hline
\end{tabular}




\begin{tabular}{|c|c|c|c|c|c|}
\hline \multirow{2}{*}{ No } & \multirow{2}{*}{ Facility Features } & \multicolumn{2}{|c|}{ Level of Importance } & \multicolumn{2}{|c|}{ Level of Performance } \\
\hline & & Mean & Std.D. & Mean & Std.D. \\
\hline 1 & Location of the Convention Centre in city & 4.53 & 0.83 & 4.73 & 1.03 \\
\hline 2 & Silence of the location & 3.87 & 0.92 & 4.47 & 0.83 \\
\hline 3 & Closeness to accommodation facilities & 4.27 & 1.10 & 4.73 & 1.03 \\
\hline 4 & Closeness to the catering facilities & 3.93 & 1.22 & 4.33 & 1.18 \\
\hline 5 & Accessibility by public transport & 4.33 & 1.05 & 4.33 & 1.23 \\
\hline 6 & Accessibility to airport and bus terminal & 3.93 & 1.22 & 3.73 & 0.96 \\
\hline 7 & Sufficient parking lot & 4.13 & 1.06 & 3.13 & 1.41 \\
\hline 8 & Directional road signage to Convention Centre & 4.20 & 0.86 & 3.27 & 1.03 \\
\hline 9 & Capacity of meeting hall & 4.27 & 1.22 & 4.13 & 0.99 \\
\hline 10 & Size of the foyer & 4.07 & 1.03 & 4.00 & 1.07 \\
\hline 11 & Sufficient WC and WC for people with disabilities & 4.33 & 1.23 & 4.00 & 0.85 \\
\hline 12 & Easy accessibility to service spaces from the meeting hall & 4.00 & 1.11 & 4.29 & 0.91 \\
\hline 13 & Availability of breakout rooms & 4.00 & 1.13 & 4.00 & 1.36 \\
\hline 14 & Availability of catering units in Convention Centre & 4.20 & 0.94 & 3.47 & 1.41 \\
\hline 15 & Proximity of catering units to meeting hall & 3.73 & 0.88 & 3.73 & 1.44 \\
\hline 16 & Placement of the stage & 4.40 & 0.91 & 4.27 & 1.10 \\
\hline 17 & Seating layout & 4.53 & 0.83 & 4.47 & 1.06 \\
\hline 18 & Availability of secondary meeting hall & 3.93 & 1.22 & 4.53 & 1.06 \\
\hline 19 & $\begin{array}{l}\text { Nonexistence of structural elements disturbing the sight angle } \\
\text { in meeting hall }\end{array}$ & 4.40 & 1.12 & 4.53 & 0.74 \\
\hline 20 & $\begin{array}{l}\text { Easy accessibility of people with disabilities throughout the } \\
\text { Centre }\end{array}$ & 4.40 & 1.18 & 3.87 & 1.25 \\
\hline 21 & Availability of info desk and bulletin board & 4.29 & 1.14 & 3.93 & 1.00 \\
\hline 22 & Comfort of the armchairs / chairs in meeting hall & 4.36 & 0.93 & 4.29 & 1.27 \\
\hline 23 & Efficiency of the illumination system & 4.53 & 1.06 & 4.47 & 1.13 \\
\hline 24 & Efficiency of ventilating and AC system & 4.73 & 1.03 & 4.40 & 1.06 \\
\hline 25 & Efficiency of the heating system & 4.60 & 1.06 & 4.13 & 1.19 \\
\hline 26 & Efficiency of the security system & 4.40 & 1.12 & 4.20 & 1.15 \\
\hline 27 & Efficiency of the audio-visual system & 4.67 & 1.05 & 4.13 & 1.25 \\
\hline 28 & Availability of elevator for people with disabilities & 4.60 & 1.06 & 3.80 & 1.26 \\
\hline 29 & Directional signage within the Convention Centre & 4.27 & 1.10 & 4.27 & 1.03 \\
\hline 30 & Simultaneous translation system and headphones & 4.17 & 1.19 & 4.17 & 1.19 \\
\hline 31 & Sufficient public internet access & 4.20 & 1.15 & 4.27 & 0.80 \\
\hline 32 & Availability of documentation instruments for public use & 4.00 & 1.31 & 4.07 & 1.10 \\
\hline 33 & Availability of communication instruments for public use & 3.80 & 1.21 & 3.93 & 0.96 \\
\hline 34 & Efficiency of the generator & 4.53 & 1.06 & 4.47 & 1.13 \\
\hline 35 & Efficiency of fire warning and extinguishing systems & 4.60 & 1.06 & 4.07 & 1.33 \\
\hline & Mean & 4.26 & & 4.13 & \\
\hline
\end{tabular}

Table 5. Employees' perception of facility features at the Convention Centre. 


\begin{tabular}{|c|c|c|c|c|c|}
\hline \multirow{2}{*}{ No } & \multirow{2}{*}{ Facility Features } & \multicolumn{2}{|c|}{ Level of Importance } & \multicolumn{2}{|c|}{ Level of Performance } \\
\hline & & Mean & Std.D. & Mean & Std.D. \\
\hline 1 & Location of the Convention Centre in city & 4.55 & 0.65 & 4.59 & 0.67 \\
\hline 2 & Silence of the location & 4.00 & 0.94 & 4.10 & 0.88 \\
\hline 3 & Closeness to accommodation facilities & 3.83 & 1.10 & 4.29 & 0.76 \\
\hline 4 & Closeness to the catering facilities & 3.60 & 1.16 & 4.08 & 0.89 \\
\hline 5 & Accessibility by public transport & 4.34 & 0.96 & 4.23 & 0.90 \\
\hline 6 & Accessibility to airport and bus terminal & 3.97 & 1.01 & 3.44 & 1.09 \\
\hline 7 & Sufficient parking lot & 4.36 & 0.92 & 3.29 & 1.15 \\
\hline 8 & Directional road signage to Convention Centre & 4.35 & 0.79 & 3.40 & 1.11 \\
\hline 9 & Capacity of meeting hall & 4.50 & 0.71 & 4.15 & 0.80 \\
\hline 10 & Size of the foyer & 4.11 & 0.85 & 4.03 & 0.81 \\
\hline 11 & Sufficient WC and WC for people with disabilities & 4.44 & 0.80 & 3.77 & 0.96 \\
\hline 12 & Easy accessibility to service spaces from the meeting hall & 4.36 & 0.72 & 3.88 & 0.84 \\
\hline 13 & Availability of breakout rooms & 4.27 & 0.79 & 3.49 & 0.99 \\
\hline 14 & Availability of catering units in Convention Centre & 4.07 & 0.80 & 3.36 & 1.10 \\
\hline 15 & Proximity of catering units to meeting hall & 3.91 & 0.90 & 3.57 & 1.02 \\
\hline 16 & Placement of the stage & 4.50 & 0.69 & 3.70 & 0.90 \\
\hline 17 & Seating layout & 4.43 & 0.81 & 3.75 & 0.91 \\
\hline 18 & Availability of secondary meeting hall & 4.03 & 0.86 & 3.65 & 0.85 \\
\hline 19 & $\begin{array}{l}\text { Nonexistence of structural elements disturbing the sight } \\
\text { angle in meeting hall }\end{array}$ & 4.23 & 0.87 & 3.88 & 0.89 \\
\hline 20 & $\begin{array}{l}\text { Easy accessibility of people with disabilities throughout the } \\
\text { Centre }\end{array}$ & 4.30 & 0.91 & 3.53 & 1.04 \\
\hline 21 & Availability of info desk and bulletin board & 4.14 & 0.87 & 3.52 & 0.94 \\
\hline 22 & Comfort of the armchairs / chairs in meeting hall & 4.31 & 0.90 & 3.51 & 0.96 \\
\hline 23 & Efficiency of the illumination system & 4.40 & 0.76 & 4.05 & 0.78 \\
\hline 24 & Efficiency of ventilating and AC system & 4.65 & 0.65 & 3.77 & 0.95 \\
\hline 25 & Efficiency of the heating system & 4.54 & 0.72 & 3.80 & 0.93 \\
\hline 26 & Efficiency of the security system & 4.32 & 0.81 & 3.84 & 0.84 \\
\hline 27 & Efficiency of the audio-visual system & 4.56 & 0.62 & 3.86 & 0.80 \\
\hline 28 & Availability of elevator for people with disabilities & 4.40 & 0.91 & 3.37 & 1.00 \\
\hline 29 & Directional signage within the Convention Centre & 4.27 & 0.74 & 3.54 & 0.93 \\
\hline 30 & Simultaneous translation system and headphones & 4.19 & 0.92 & 3.60 & 1.02 \\
\hline 31 & Sufficient public internet access & 4.07 & 0.91 & 3.47 & 0.98 \\
\hline 32 & Availability of documentation instruments for public use & 3.63 & 0.98 & 3.13 & 1.02 \\
\hline 33 & Availability of communication instruments for public use & 3.61 & 0.99 & 3.06 & 0.99 \\
\hline 34 & Efficiency of the generator & & & & \\
\hline \multirow[t]{2}{*}{35} & Efficiency of fire warning and extinguishing systems & & & & \\
\hline & Mean & 4.22 & & 3.72 & \\
\hline
\end{tabular}

Table 6.Attendees' perception of facility features at the Convention Centre. 